\title{
RASGRF1 Gene
}

National Cancer Institute

\section{Source}

National Cancer Institute. RASGRF1 Gene. NCI Thesaurus. Code C42625.

This gene is involved in signal transduction and putatively plays a role in long-term

memory. 